\title{
EXPERIMENTALWORKS
}

UDC 577.13:581.1

doi: https://doi.org/10.15407/ubj90.06.012

\section{PHENYLALANINE AMMONIA-LYASE ACTIVITY \\ AND CONTENT OF FLAVONOID COMPOUNDS IN WHEAT \\ SEEDLINGS AT THE ACTION OF HYPOTHERMIA AND HYDROGEN SULFIDE DONOR}

\author{
Yu. E. KOLUPAEV $V^{1,2}$, E. I. HORIELOVA ${ }^{1}$, T. O. YASTREB ${ }^{1}$, \\ Yu. V. POPOV ${ }^{3}$, N. I. RYABCHUN ${ }^{3}$ \\ ${ }^{1}$ Dokuchaev Kharkiv National Agrarian University, Ukraine; \\ e-mail:plant_biology@ukr.net; \\ ${ }^{2}$ Karazin Kharkiv National University, Ukraine; \\ ${ }^{3}$ Yuryev Plant Production Institute, National Academy \\ of Agrarian Sciences of Ukraine, Kharkiv
}

At present hydrogen sulfide $\left(\mathrm{H}_{2} \mathrm{~S}\right)$ is considered as one of the signal mediators in plant cells. However, its role in formation of plant resistance to low temperatures and, in particular, in regulation of secondary metabolism under stress conditions remains poorly understood. The influence of $\mathrm{H}_{2} \mathrm{~S}$ donor sodium hydrosulfide (NaHS) on phenylalanine ammonia-lyase (PAL) activity and content of flavonoids in wheat seedlings at normal temperature $\left(21^{\circ} \mathrm{C}\right)$ and under cold hardening conditions $\left(7\right.$ days at $\left.3{ }^{\circ} \mathrm{C}\right)$ was studied. After 2 days of the hardening temperature, a transient increase in PAL activity was noted. Also, activity of the enzyme was increased by treatment of plants with 0.1 or $0.5 \mathrm{mM} \mathrm{NaHS} \mathrm{under} \mathrm{normal} \mathrm{temperature} \mathrm{conditions} \mathrm{and} \mathrm{especially}$ at the background of cold hardening. By themselves, the cold hardening and the action of $\mathrm{H}_{2} \mathrm{~S}$ donor caused an increase in total content of flavonoids and amount of anthocyanins. With the combination of hypothermia and treatment of seedlings with NaHS, this effect enlarged and the total content of flavonoids increased by 3.8, and anthocyanins increased by 1.8 times in comparison to the control. Treatment with the $\mathrm{H}_{2} \mathrm{~S}$ donor caused a decrease in content of the lipid peroxidation product malonic dialdehyde in seedlings after the action of hardening temperature, and especially after their freezing at $-5^{\circ} \mathrm{C}$. Also, under the influence of NaHS, survival of hardened and unhardened seedlings after cryostress increased. It was concluded that one of the mechanisms of the positive influence of the $\mathrm{H}_{2} \mathrm{~S}$ donor on resistance of wheat seedlings to hypothermia is the $P A L$-dependent accumulation of flavonoid compounds, which have a high antioxidant activity, and a decrease in effects of secondary oxidative stress.

Key words: hydrogen sulfide $\left(H_{2} S\right)$, phenylalanine ammonia-lyase, flavonoids, lipid peroxidation, frost resistance, Triticum aestivum.

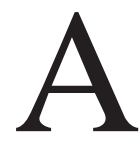
$t$ present, the functions of hydrogen sulfide $\left(\mathrm{H}_{2} \mathrm{~S}\right)$ as a signal mediator in mammalian cells have been well studied; its involvement in regulation of vascular tone, neuromodulation, cytoprotection, inflammation, and apoptosis was established [1-3]. The role of hydrogen sulfide in plant cells is investigated significantly weaker, but recently $\mathrm{H}_{2} \mathrm{~S}$ molecules, along with nitrogen monoxide and carbon monoxide, are classed as the key gasotransmitters of plant cells [4].

It is assumed that hydrogen sulfide plays an important role in transduction of stress signals in plant cells and in formation of adaptive reactions [5]. Data was received on the changes in endogenous $\mathrm{H}_{2} \mathrm{~S}$ con-

\footnotetext{
(C) 2018 Kolupaev Yu. E. et al. This is an open-access article distributed under the terms of the Creative Commons Attribution License, which permits unrestricted use, distribution, and reproduction in any medium, provided the original author and source are credited.
} 
tent in plant cells in response to effect of external stimuli on plants [6, 7]. An induction by exogenous hydrogen sulfide of a number of plant protective systems was revealed [8-10]. Using molecular biological approaches, it was shown that hydrogen sulfide most significantly influenced expression of genes of proteins associated with carbohydrate metabolism, secondary metabolism, and synthesis of low-molecular-weight antioxidants [11].

However, an effect of hydrogen sulfide donors on resistance of plants to some stress factors, in particular to hypothermia, remains poorly understood. Among the grasses capable of surviving after an action of negative temperatures, the influence of hydrogen sulfide has been studied only on Bermuda grass (Cynodon dactylon L.) [12]. An increase in activity of antioxidant enzymes in these plants was observed when they were treated with $500 \mu \mathrm{M}$ NaHS before the action of hardening temperature of $4{ }^{\circ} \mathrm{C}$, as well as in their survival at subsequent freezing at $-10^{\circ} \mathrm{C}$.

One of the important causes of damage to plants at low temperatures is secondary oxidative stress. Since increasing viscosity of lipid part of cell membranes is one of the most frequent effects of hypothermia on plants, membrane-bound processes such as respiration and photosynthesis are more sensitive to temperature stress compared to processes occurring outside membranes involving soluble enzymes. If membrane-associated processes and processes in matrix of mitochondria and stroma of chloroplasts are not coordinated for one reason or another, then there is a possibility of accepting electrons from carriers of electron transport chain by molecular with formation of reactive oxygen species (ROS) $[13,14]$. It is these processes that can occur when the state of lipids of internal membranes in mitochondria and chloroplasts is changed because of cold. ROS, formed as a result of failures in operation of electron transport chains, can subsequently initiate non-enzymatic reactions, leading to an additional increase in their amount.

In this regard, activation of antioxidant system is considered as one of the important mechanisms of plant adaptation to the action of cold [15]. There are data on the ability of hydrogen sulfide donors to induce antioxidant enzymes in plants under an action of stressors of a different nature, and also contribute to the accumulation of low-molecular antioxidants ascorbate and glutathione [10, 12, 16-18].

Important low-molecular-weight antioxidants include flavonoids [19]. Of particular note is the high antioxidant activity of anthocyanins, which are able to effectively deactivate superoxide anion radicals [20]. An increase in total content of flavonoids [21] and amount of anthocyanins [22] was shown in the low-temperature adaptation of wheat. However, the influence of hydrogen sulfide on content of flavonoid compounds in plants is poorly understood. In fruits of bananas, at low-temperature storage, under the influence of the hydrogen sulfide donor NaHS an increase in the total content of phenolic compounds and the activity of phenylalanine ammonia-lyase (PAL, EC 4.3.1.5) was noted [23]. PAL, converting L-phenylalanine to trans-cinnamic acid, which is the precursor of most secondary metabolites, is considered the starting enzyme in complex processes for synthesis of flavonoids [21, 24]. However, when stored broccoli plants were treated with hydrogen sulfide donor, there was a decrease in PAL activity and anthocyanin content, although there was some increase in total content of flavonoids [17]. Li et al. [25] study, performed on maize seedlings, did not observe any significant changes in PAL activity under the influence of hydrogen sulfide donor treatment, which induced the development of heat resistance. Thus, information on the effect of hydrogen sulfide on the functioning of secondary metabolism in plants under normal and stress conditions is few and very contradictory.

In connection with the foregoing, the purpose of this work was to study the influence of the hydrogen sulfide donor NaHS on the activity of PAL, and content of flavonoid compounds in wheat seedlings under physiologically normal conditions and during cold hardening, and also to evaluate the effect of exogenous NaHS on the basic and induced by hardening frost resistance of plants.

\section{Materials and Methods}

The work was carried out on etiolated seedlings of winter wheat (Triticum aestivum L.) of cv. Doskonala. Seeds were disinfected in $6 \%$ solution of hydrogen peroxide for $40 \mathrm{~min}$, thoroughly washed several times with distilled water and then germinated at $21 \pm 1{ }^{\circ} \mathrm{C}$ on filter paper moistened with purified tap water.

In the series of experiments to investigate the influence of hydrogen sulfide donor on resistance of seedlings to cryostress, sodium hydrosulfide (NaHS) in concentrations of $0.025-1 \mathrm{mM}$ was added to the medium at the beginning of seed germination and on the third day. After 4 days, seedlings were used 
for biochemical analyzes and were frozen in the refrigerate chamber (Danfoss, Holland) at $-5^{\circ} \mathrm{C}$ for $4 \mathrm{~h}$, with the temperature descending $1^{\circ} \mathrm{C} / \mathrm{h}$. To thaw seedlings, the temperature in the chamber was increased at $1{ }^{\circ} \mathrm{C} / \mathrm{h}$ up to $2{ }^{\circ} \mathrm{C}$. Afterwards, the seedlings were grown for 3 days at $21 \pm 1{ }^{\circ} \mathrm{C}$ and $6 \mathrm{klx}$ illumination, and their survival was evaluated.

In experiments to study the effect of hydrogen sulfide donor on the development of frost resistance at hardening, 3-day-old seedlings were treated with NaHS and placed for 7 days in the refrigerate chamber at $3 \pm 1^{\circ} \mathrm{C}$. After 3 days of hardening, seedlings of corresponding variants were re-treated with solutions of sodium hydrosulfide. Control seedlings during the hardening were incubated on on filter paper moistened with purified tap water.The optimal hardening regime, which maximizes frost resistance of seedlings, was established earlier [26]. For comparison, 4-day-old seedlings that had not been hardened (see above) were used. Since the development of seedlings slowed down at low temperatures, 10 -day hardened plants were the same as the 4-day control plants grown at $21 \pm 1{ }^{\circ} \mathrm{C}$.

Hardened seedlings were allowed to freeze at $-5^{\circ} \mathrm{C}$ for $4 \mathrm{~h}$, decreasing the temperature at the rate of $1^{\circ} \mathrm{C} / \mathrm{h}$. The samples were then thawed and grown to evaluate survival as described above.

The activity of PAL was determined by the formation of trans-cinnamic acid from L-phenylalanine according to Zucker [27] with modifications [21]. Shoots of seedlings were homogenized in $0.1 \mathrm{M}$ borate buffer ( $\mathrm{pH} 8.8$ ) containing $0.5 \mathrm{mM}$ EDTA and $3 \mathrm{mM}$ dithiothreitol at a temperature no more than $4{ }^{\circ} \mathrm{C}$, and then extracted for 30 minutes at the same temperature. The homogenate was centrifuged at $8000 \mathrm{~g}$ for $20 \mathrm{~min}$ at $4^{\circ} \mathrm{C}$ on the MPW 350R centrifuge (MedInstruments, Poland). The supernatant was used to determine the enzymatic activity. The reaction mixture, consisting of $0.5 \mathrm{ml}$ supernatant, $1.5 \mathrm{ml}$ borate buffer ( $\mathrm{pH} 8.8$ ) and $2 \mathrm{ml} 50 \mathrm{mM}$ L-phenylalanine, was incubated in the thermostat for 1 hour at $37^{\circ} \mathrm{C}$. At the end of the incubation, the optical density at $290 \mathrm{~nm}$ was immediately determined by the spectrophotometer SF 46 (LOMO, Russia). Optical control was an identical mixture with the enzymatic extract inactivated by boiling. The protein content was determined by Bradford [28]. The activity of PAL was expressed in nmol of trans-cinnamic acid/(mg protein hour).

The total content of flavonoids was determined by the formation of a complex with aluminum ions
[29]. The plant material was homogenized in $70 \%$ ethanol; extraction was carried out for 20 minutes at room temperature. The extract was mixed with $1 \%$ solution of $\mathrm{AlCl}_{3}$ in $95 \%$ ethanol in ratio 1:1, and its absorbance at $414 \mathrm{~nm}$ was determined relative to the sample containing all of the components of the mixture except the aluminum salt. Rutin was used as the standard. The content of flavonoids was expressed in $\mu \mathrm{mol}$ rutin per $\mathrm{g}$ of dry weight.

To detect anthocyanin content, plant shoots samples were disrupted in $1 \% \mathrm{HCl}$ in methanol. After homogenate centrifugation for $15 \mathrm{~min}$ at $8000 \mathrm{~g}$, the supernatant optical density was read at $530 \mathrm{~nm}$ [30]. The content of anthocyanins was expressed in $\mu$ mol of cyanidin-3-glucoside per $g$ of dry weight.

Intensity of the lipid peroxidation (LPO) in seedling tissues was determined by evaluating the amount of the products interacting with 2-thiobarbituric acid (mainly malonic dialdehyde - MDA) as described earlier [26]. The MDA content was expressed in nmol/g of dry weight.

Repeat of independent experiments 3-fold with 3 -fold biological replicates in each. The figures show the means and their standard errors. Unless otherwise specified, differences are discussed, which are significant at $P \leq 0.05$.

\section{Results and Discussion}

In the first series of experiments, the effect of treatment of seedlings with NaHS in various concen-

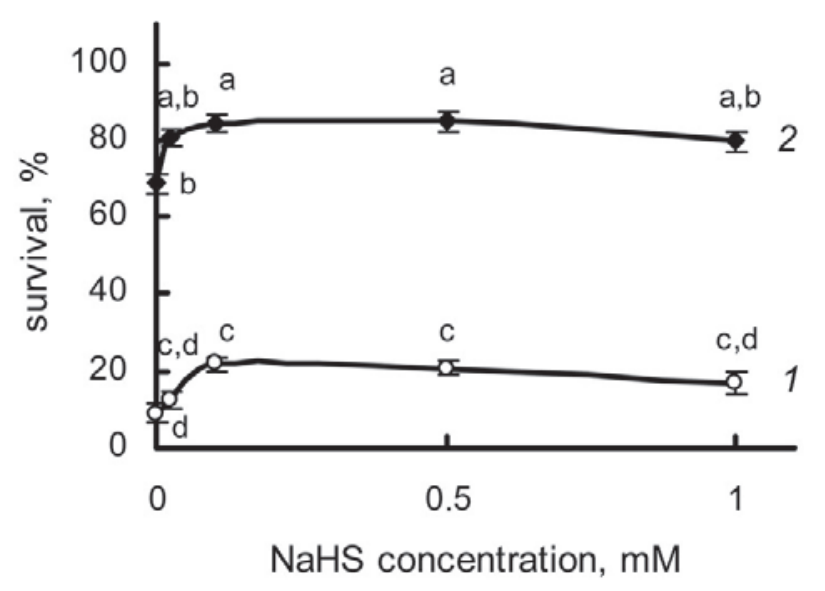

Fig. 1. Influence of $\mathrm{H}_{2} \mathrm{~S}$ donor sodium hydrosulfide on survival (\%) of wheat seedlings after freezing for 4 hours at $-5{ }^{\circ} \mathrm{C} .1$ - Unhardened seedlings, 2 - hardening $\left(3{ }^{\circ} \mathrm{C}, 7\right.$ days). Here and in Fig. 2-4: values followed by the same letter are not significantly different $(P \leq 0.05)$ 
trations and cold hardening on their survival after freezing at $-5^{\circ} \mathrm{C}$ was studied. The frost resistance of unhardened wheat seedlings was very low (Fig. 1). Under the influence of hydrogen sulfide donor treatment, there was a significant increase. The most effective NaHS concentrations were 0.1 and $0.5 \mathrm{mM}$.

Under the influence of cold hardening, the resistance of seedlings to freezing increased significantly (Fig. 1). At the same time, treatment of seedlings with NaHS on the background of hardening caused an additional increase in their frost resistance. Due to the fact that the greatest positive effect was manifested when treated seedlings with 0.1 and $0.5 \mathrm{mM}$ sodium hydrosulfide, in subsequent experiments, when studying the influence of the hydrogen sulfide donor on the biochemical parameters of the seedlings, precisely such concentrations were used.

Treatment of wheat seedlings with hydrogen sulfide donor under normal temperature conditions caused an increase in the PAL activity by $35-45 \%$ (Fig. 2).

After 2 days of the hardening temperature $\left(3{ }^{\circ} \mathrm{C}\right)$ influence, a relatively small but significant at $P \leq 0.05$ increase in activity of the enzyme was observed; later (on 5 and 7th day) it was on the level of control samples that had not undergone hardening.

Treatment of seedlings with the $\mathrm{H}_{2} \mathrm{~S}$ donor contributed to the maintenance of increased PAL activity during the entire period of cold hardening (Fig. 2). Especially high enzyme activity in variants with 0.1 and $0.5 \mathrm{mM}$ NaHS treatment was after 2 days of hardening: it exceeded the control values (without hardening and NaHS treatment) by 43 and $69 \%$, respectively.

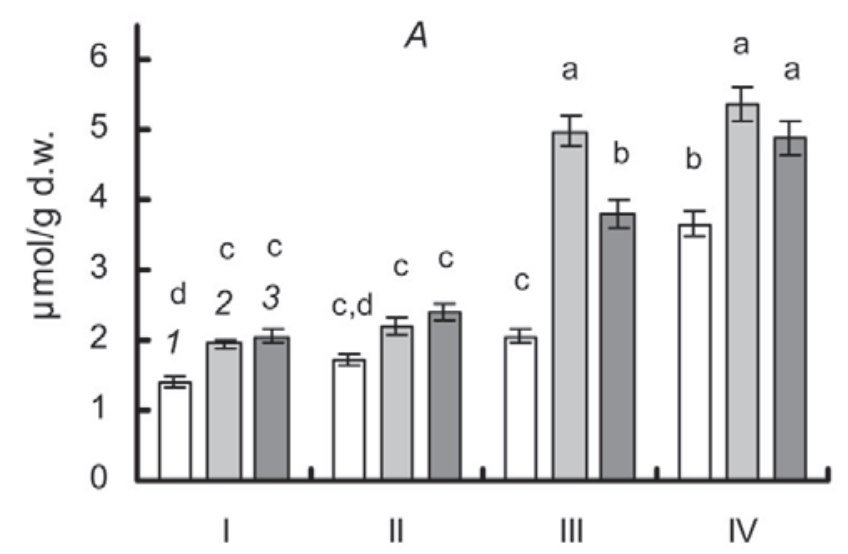

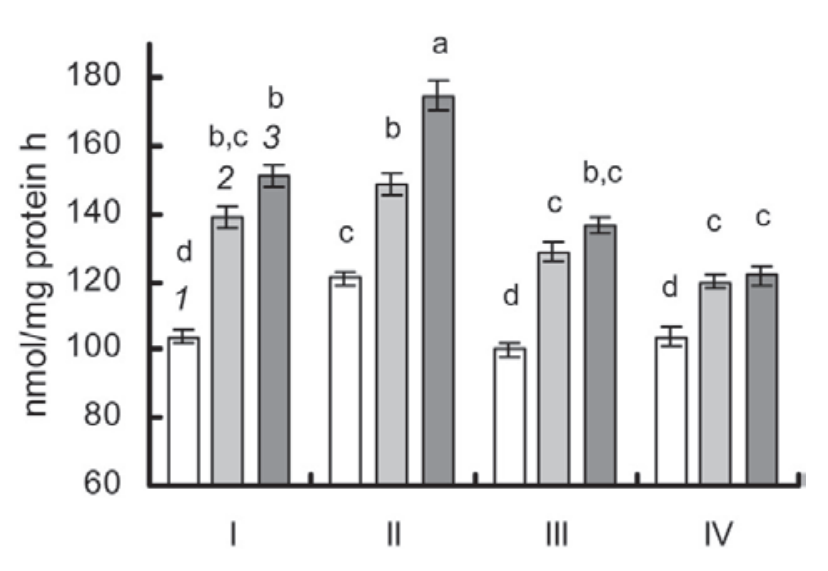

Fig. 2. Activity of PAL (nmol/(mg protein h) in wheat seedlings: I-without hardening; II-IV - 2, 5, and 7 days of hardening, respectively. 1 - Control, $2-$ NaHS (0.1 mM), 3 - NaHS (0.5 mM)

Under the influence of the hydrogen sulfide donor in the seedlings at normal temperature the total content of flavonoids and the amount of anthocyanins increased (Fig. 3).

In the process of cold hardening, gradual accumulation of flavonoids occurred, incl. anthocyanins, which reached the maximum values after 7 days of low-temperature action. At the same time, NaHS treatment promoted a significant additional accumulation of flavonoid compounds. In variants with the hydrogen sulfide donor treatment, the largest values of the total content of flavonoids and anthocyanins were noted after 5 and 7 days of hardening (Fig. 3). At the end of hardening, the total content of flavonoids in variants with NaHS increased by 3.8 times

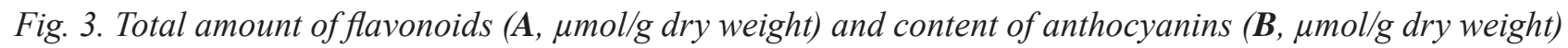
in wheat seedlings: I - without hardening; II-IV - 2, 5, and 7 days of hardening, respectively. 1 - Control, 2 - NaHS (0.1 mM), 3 - NaHS (0.5 mM) 


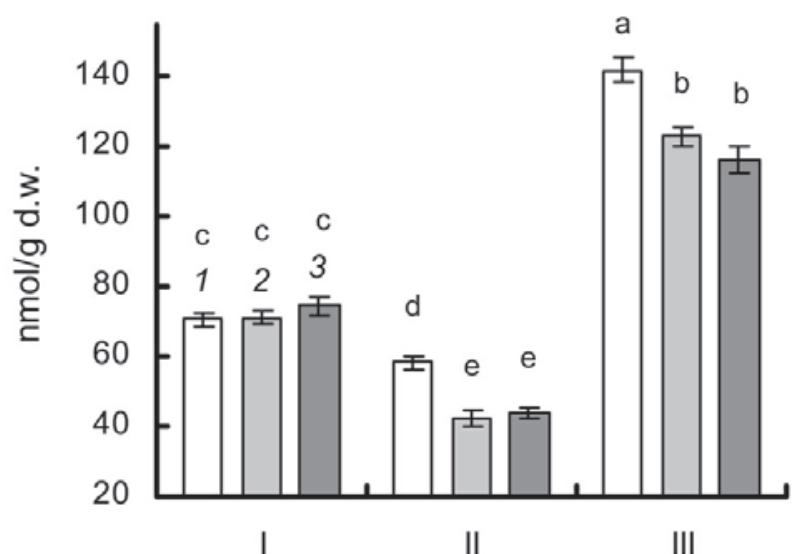

Fig. 4. Content of TBA-active products (nmol MDA/g dry weight) in wheat seedlings. I - Without hardening; II-after hardening ( $\left(7\right.$ days at $\left.3{ }^{\circ} \mathrm{C}\right)$; IIIafter freezing of hardened seedlings $\left(4 \mathrm{~h}\right.$ at $\left.-5^{\circ} \mathrm{C}\right)$. 1 - Control, 2 - NaHS (0.1 mM), 3 - NaHS (0.5 mM)

in comparison with unhardened control, and the content of anthocyanins increased 1.8-fold.

The content of LPO product at the treatment of seedlings with the hydrogen sulfide donor NaHS under normal temperature conditions did not change (Fig. 4). Low-temperature hardening in itself caused a significant decrease in MDA content in shoots of seedlings. At the same time, in the variants with the combination of hardening and NaHS treatment, values of the LPO product content were lower than in the variant with hardening only. After freezing of hardened seedlings, the MDA content in them increased substantially, this reflected the development of cold injuries that preceded death of seedlings. At the same time, in seedlings that were treated with a hydrogen sulfide donor during hardening, it was lower than in untreated ones (Fig. 4).

Thus, the influence of the hydrogen sulfide donor on wheat seedlings grown at normal temperature induced their resistance to low-temperature stress; under the influence of NaHS, the positive effects of cold hardening of plants also improved, which was expressed in an increase in the relative number of plants that survived after freezing (Fig. 1).

At least one of the reasons for the positive influence of the hydrogen sulfide donor on the basic and cold-hardening-induced resistance of seedlings to cryostress may be a decrease of the secondary oxidative stress effect under its influence. This is evidenced by a smaller accumulation of the LPO product MDA in seedlings of variants with $\mathrm{NaHS}$ treatment under cold hardening conditions and especially after the action of cryostress $\left(-5^{\circ} \mathrm{C}\right)$ (Fig. 4).

In turn, one of the reasons for mitigating the manifestations of the oxidative stress caused by the negative temperature can be the accumulation of flavonoid compounds in wheat seedlings at the influence of exogenous hydrogen sulfide. Under the conditions of our experiments, the activation of secondary metabolism was observed at the treatment of NaHS. This was manifested, in particular, in increasing the PAL activity in variants with the hydrogen sulfide donor influence both under normal temperature conditions and during cold hardening (Fig. 2). It should be noted that the activity of PAL in wheat seedlings increased under the influence of the hardening temperature $\left(3^{\circ} \mathrm{C}\right)$ too, although this increase was transient and it was fixed only 2 days after the start of the hardening. It is noteworthy that in the work performed on adult green wheat plants, it was not detected an increase in PAL activity after cold hardening [21]. Perhaps this is due to the fact that, in this work, the enzyme activity was investigated not in dynamics during the formation of resistance by hardening, but only once, at its end.

Under the conditions of our experiments, the increase in PAL activity after the influence of cold hardening, the hydrogen sulfide donor or their combinations led to an increase in the content of flavonoids, including anthocyanins (Fig. 3). In the variant with hardening, the increase in PAL activity was manifested on the $2^{\text {nd }}$ day, while the increase in the content of flavonoid compounds was on the 5-7 $7^{\text {th }}$ days after the start of the hardening. Such a temporal dynamics indicates a causal relationship between the activation of PAL and the accumulation of flavonoids in seedlings (Fig. 2, 3). It can not be ruled out, however, that the factors we studied (cold and hydrogen sulfide) directly or indirectly influenced the processes of flavonoids degradation, slowing them down. In Olenichenko et al. work [21], it was shown an increase in the flavonoids content in leaves of wheat during cold hardening against the background of a decrease in the PAL activity. Such effects indicate the possibility of accumulation of flavonoids due to slowing down of their degradation.

As already noted, the literature data on the effect of hydrogen sulfide on PAL activity and the course of secondary metabolism are few and partly contradictory. In our experiments conducted earlier, a significant increase in the amount of anthocyanins under the $0.5 \mathrm{mM}$ NaHS influence in etiolated 
wheat seedlings under normal conditions and under osmotic stress was shown [31]. Also, under the influence of the hydrogen sulfide donor, there was an increase in the content of flavonoids, absorbing in UV-B, in leaves. It can be assumed that the accumulation of flavonoid compounds is one of the important mechanisms for the protective action of the hydrogen sulfide donor on plants under stresses of a different nature [31]. In accordance with this assumption, there are some results obtained at other objects. So, an increase in the content of colorless flavonoids (absorbing UV) and anthocyanins in barley plants was revealed when they were induced to UV-B resistance by treatment with hydrogen sulfide donor [32]. Recently, the increase under the NaHS influence of the total content of flavonoids and the amount of anthocyanins at the low-temperature storage of hawthorn fruits has been shown [33]. When storing the lotus roots (Nelumbo nucifera Gaertn.) at a low temperature, under the influence of hydrogen sulfide the activity of PAL and the content of phenolic compounds increased [34]. On the other hand, as already noted, when the broccoli was stored, under the influence of hydrogen sulfide donor, an increase in the total content of flavonoids occurred against a background of a decrease in PAL activity [17]. Moreover, in the variant with sodium hydrosulfide treatment, despite an increase in the total content of flavonoids, the amount of anthocyanins decreased. Perhaps such effects are associated with complex interconversion of secondary metabolites and are a feature of this object.

Discussing the results obtained by us, it should be noted that enhancement of secondary metabolism and accumulation of flavonoid compounds, apparently, is by no means the only mechanism of increasing resistance of plants to oxidative stress by exogenous hydrogen sulfide. Thus, when heat resistance of maize seedlings was induced by the hydrogen sulfide donor, there was an increase of a pool of reduced ascorbate and glutathione [10]. In our experiments, an increase in heat resistance of wheat coleoptile cells by treatment with NaHS was accompanied by an increase in the activity of superoxide dismutase and guaiacol peroxidase [18]. Similar effects were observed in wheat seedlings treated with the hydrogen sulfide donor before osmotic stress [31]. In addition, the treatment of wheat seedlings with sodium hydrosulfide during osmotic stress increased in leaves the content of proline [31], which is not only an osmolite but also an antioxidant [35].
Thus, exogenous hydrogen sulfide apparently induces many components of the primary and secondary metabolism necessary for the development of plant resistance to action of stress factors. Activation of the antioxidant system, necessary to protect plant cells from action of secondary oxidative stress, may be one of the reasons for cross resistance to stress factors of various nature, induced by hydrogen sulfide [12]. In further studies, it is of interest to elucidate the functional interaction of hydrogen sulfide with other signal mediators, in particular ROS and nitric oxide, upon activation of plant protective systems [36]. The effects of secondary metabolism activation, induced by hydrogen sulfide in the present work, can be a model for such studies.

\section{АКТИВНІСТЬ \\ ФЕНІЛАЛАНІНАМОНІЙЛІАЗИ І ВМІСТ ФЛАВОНОЇДНИХ СПОЛУК У ПРОРОСТКАХ ПШЕНИЦІ ЗА ДІЇ ГІПОТЕРМІЇ ТА ДОНОРА ГІДРОГЕН СУЛЬФІДУ}

\author{
Ю. Є. Колупаєв ${ }^{1,2}$, О. І. Горєлова ${ }^{1}$, \\ T. О. Ястреб
}

\footnotetext{
${ }^{1}$ Харківський національний аграрний університет ім. В. В. Докучаєва, Україна; e-mail: plant_biology@ukr.net;

${ }^{2}$ Харківський національний університет ім. В. Н. Каразіна, Україна;

${ }^{3}$ Інститут рослинництва ім. В. Я. Юр'єва НААН України, Харків
}

Нині гідроген сульфід $\left(\mathrm{H}_{2} \mathrm{~S}\right)$ розглядається як один із сигнальних посередників у рослинних клітинах. Однак його роль у формуванні стійкості рослин до низьких температур і особливо в регуляції вторинного метаболізму за стресових умов залишається маловивченою. Досліджували вплив донора $\mathrm{H}_{2} \mathrm{~S}$ - гідросульфіду натрію (NaHS) - на активність фенілаланінамонійліази (ФАЛ) і вміст флавоноїдів у проростках пшениці за звичайної температури $\left(21^{\circ} \mathrm{C}\right)$ і умов холодового загартовування (7 діб при $\left.3{ }^{\circ} \mathrm{C}\right)$. Через 2 доби дії загартовувальної температури відзначалося транзиторне підвищення активності ФАЛ. Також активність ензиму збільшувалася під впливом обробки проростків 0,1 або 0,5 мМ NaHS у звичайних температурних умовах і особливо на фоні холодового загартовування. Самі по собі холодове загартовування і дія донора $\mathrm{H}_{2} \mathrm{~S}$ спричинювали підвищення загального вмісту 
флавоноїдів і кількості антоціанів. Поєднання гіпотермії і обробки проростків NaHS цей ефект посилювало і збільшувало загальний вміст флавоноїдів в 3,8 , а антоціанів - в 1,8 раза порівняно 3 контролем. Обробка донором $\mathrm{H}_{2} \mathrm{~S}$ зменшувала вміст продукту пероксидного окислення ліпідів малонового діальдегіду в проростках після дії загартовувальної температури і особливо після ïx проморожування при $-5^{\circ} \mathrm{C}$. Також під впливом обробки NaHS підвищувалася виживаність загартованих і незагартованих проростків після кріостресу. Дійшли висновку, що одним із механізмів позитивного впливу донора $\mathrm{H}_{2} \mathrm{~S}$ на стійкість проростків пшениці до гіпотермії $€$ залежне від активності ФАЛ накопичення флавоноїдних сполук, яким притаманна висока антиоксидантна активність, і зменшення наслідків вторинного окислювального стресу.

К л ю ч о в і с ло в а: гідроген сульфід, фенілаланінаммонійліаза, флавоноїди, пероксидне окислення ліпідів, морозостійкість, Triticum aestivum.

\section{АКТИВНОСТЬ ФЕНИЛАЛАНИНАММОНИЙЛИАЗЫ И СОДЕРЖАНИЕ ФЛАВОНОИДНЫХ СОЕДИНЕНИЙ В ПРОРОСТКАХ ПШЕНИЦЫ ПРИ ДЕЙСТВИИ ГИПОТЕРМИИ И ДОНОРА СЕРОВОДОРОДА}

Ю. Е. Колупаев ${ }^{1,2}$, Е. И. Горелова
Т. О. Ястреб, Ю. В. Попов ${ }^{3}$, Н. И. Рябчун

\footnotetext{
${ }^{1}$ Харьковский национальный аграрный университет им. В. В. Докучаева, Украина; e-mail: plant_biology@ukr.net;

${ }^{2}$ Харьковский национальный университет им. В. Н. Каразина, Украина;
}

${ }^{3}$ Институт растениеводства им. В. Я. Юрьева НААН Украины, Харьков

В настоящее время сероводород $\left(\mathrm{H}_{2} \mathrm{~S}\right)$ рассматривается как один из сигнальных посредников в растительных клетках. Однако его роль в формировании устойчивости растений к низким температурам и в особенности в регуляции вторичного метаболизма в стрессовых условиях остается малоизученной. Исследовали влияние донора $\mathrm{H}_{2} \mathrm{~S}$ - гидросульфида натрия (NaHS) на активность фенилаланинаммонийлиазы (ФАЛ) и содержание флавоноидов в проростках пшеницы при обычной температуре $\left(21^{\circ} \mathrm{C}\right)$ и в условиях холодового закаливания (7 суток при $\left.3{ }^{\circ} \mathrm{C}\right)$. Через двое суток действия закаливающей температуры отмечалось транзиторное повышение активности ФАЛ. Также активность энзима увеличивалась под влиянием обработки проростков 0,1 или 0,5 мM NaHS в обычных температурных условиях и особенно на фоне холодового закаливания. Сами по себе холодовое закаливание и действие донора $\mathrm{H}_{2} \mathrm{~S}$ вызывали повышение общего содержания флавоноидов и количества антоцианов. При сочетании гипотермии и обработки проростков NaHS этот эффект усиливался и общее содержание флавоноидов увеличивалось в 3,8 , а антоцианов - в 1,8 раза по сравнению с контролем. Обработка донором $\mathrm{H}_{2} \mathrm{~S}$ вызывала уменьшение содержания продукта пероксидного окисления липидов малонового диальдегида в проростках после действия закаливающей температуры и особенно после их промораживания при $-5{ }^{\circ} \mathrm{C}$. Также под влиянием обработки NaHS повышалось выживание закаленных и незакаленных проростков после криостресса. Сделано заключение, что одним из механизмов положительного влияния доноpa $\mathrm{H}_{2} \mathrm{~S}$ на устойчивость проростков пшеницы к гипотермии является зависимое от активности ФАЛ накопление флавоноидных соединений, обладающих высокой антиоксидантной активностью, и уменьшение последствий вторичного окислительного стресса.

К л ю че вы е с лова: сероводород $\left(\mathrm{H}_{2} \mathrm{~S}\right)$, фенилаланинаммонийлиаза, флавоноиды, пероксидное окисление липидов, морозоустойчивость, Triticum aestivum.

\section{References}

1. Łowicka E, Bełtowski J. Hydrogen sulfide (H2S) the third gas of interest for pharmacologists. Pharmacol Rep. 2007; 59(1): 4-24.

2. Gadalla MM, Snyder SH. Hydrogen sulfide as a gasotransmitter. J Neurochem. 2010; 113(1): 1426.

3. Zaichko NV, Melnik AV, Yoltukhivskyy MM, Olhovskiy AS, Palamarchuk IV. Hydrogen sulfide: metabolism, biological and medical role. Ukr Biochem J. 2014; 86(5): 5-25.

4. He H, He LF. Regulation of gaseous signaling molecules on proline metabolism in plants. Plant Cell Rep. 2018; 37(3): 387-392. 
5. Hancock JT, Whiteman M. Hydrogen sulfide signaling: interactions with nitric oxide and reactive oxygen species. Ann N Y Acad Sci. 2016; 1365(1): 5-14.

6. Jin Z, Xue S, Luo Y, Tian B, Fang H, Li H, Pei Y. Hydrogen sulfide interacting with abscisic acid in stomatal regulation responses to drought stress in Arabidopsis. Plant Physiol Biochem. 2013; 62: 41-46.

7. Lai D, Mao Y, Zhou H, Li F, Wu M, Zhang J, He Z, Cui W, Xie Y. Endogenous hydrogen sulfide enhances salt tolerance by coupling the reestablishment of redox homeostasis and preventing salt-induced $\mathrm{K}^{+}$loss in seedlings of Medicago sativa. Plant Sci. 2014; 225: 117-129.

8. Wang Y, Li L, Cui W, Xu S., Shen W, Wang R. Hydrogen sulfide enhances alfalfa (Medicago sativa) tolerance against salinity during seed germination by nitric oxide pathway. Plant Soil. 2012; 351(1-2): 107-119.

9. Li ZG. Hydrogen sulfide: a multifunctional gaseous molecule in plants. Russ J Plant Physiol. 2013; 60(6): 733-740.

10. Li ZG, Yi XY, Li YT. Effect of pretreatment with hydrogen sulfide donor sodium hydrosulfide on heat tolerance in relation to antioxidant system in maize (Zea mays) seedlings. Biologia. 2014; 69(8): 1001-1009.

11. Ding $H$, Han $Q$, Ma $D$, Hou J, Huang $X$, Wang C, Xie Y, Kang G, Guo T. Characterizing physiological and proteomic analysis of the action of $\mathrm{H}_{2} \mathrm{~S}$ to mitigate drought stress in young seedling of wheat. Plant Mol Biol Rep. 2018; 36(1): 45-57.

12. Shi H, Ye T, Chan Z. Exogenous application of hydrogen sulfide donor sodium hydrosulfide enhanced multiple abiotic stress tolerance in bermudagrass (Cynodon dactylon (L). Pers.). Plant Physiol Biochem. 2013; 71: 226-234.

13. Piotrovskii MS, Shevyreva TA, Zhestkova IM, Trofimova MS. Activation of plasmalemmal NADPH oxidase in etiolated maize seedlings exposed to chilling temperatures. Russ J Plant Physiol. 2011; 58(2): 290-298.

14. Kolupaev YuE, Karpets YuV. Reactive oxygen species and stress signaling in plants. $U k r$ Biochem J. 2014; 86(4): 18-35. (In Russian).

15. Janmohammadi M, Enayati V, Sabaghnia N. Impact of cold acclimation, de-acclimation and re-acclimation on carbohydrate content and antioxidant enzyme activities in spring and winter wheat. Icel Agric Sci. 2012; 25: 3-11.
16. Christou A, Manganaris GA, Papadopoulos I, Fotopoulos V. Hydrogen sulfide induces systemic tolerance to salinity and non-ionic osmotic stress in strawberry plants through modification of reactive species biosynthesis and transcriptional regulation of multiple defence pathways. $J$ Exp Bot. 2013; 64(7): 1953-1966.

17. Li SP, Hu KD, Hu LY, Li YH, Jiang AM, Xiao F, Han Y, Liu YS, Zhang H. Hydrogen sulfide alleviates postharvest senescence of broccoli by modulating antioxidant defense and senescencerelated gene expression. J Agric Food Chem. 2014; 62(5): 1119-1129.

18. Kolupaev YuE, Firsova EN, Yastreb TO. Induction of plant cells heat resistance by hydrogen sulfide donor is mediated by $\mathrm{H}_{2} \mathrm{O}_{2}$ generation with participation of NADPH oxidase and superoxide dismutase. Ukr Biochem J. 2017; 89(4): 34-42.

19. Khlestkina EK. The adaptive role of flavonoids: emphasis on cereals. Cereal Res Commun. 2013; 41(2): 185-198.

20. Neill SO, Gould KS. Anthocyanins in leaves: light attenuators or antioxidants? Funct Plant Biol. 2003; 30(8): 865-873.

21. Olenichenko NA, Zagoskina NV, Astakhova NV, Trunova TI, Kuznetsov YuV. Primary and secondary metabolism of winter wheat under cold hardening and treatment with antioxidants. Appl Biochem Microbiol. 2008; 44(5): 535-540.

22. Kolupaev YuE, Yastreb TO, Oboznyi AI, Ryabchun NI, Kirichenko VV. Constitutive and cold-induced resistance of rye and wheat seedlings to oxidative stress. Russ J Plant Physiol. 2016; 63(3): 326-337.

23. Luo Z, Li D, Du R, Mou W. Hydrogen sulfide alleviates chilling injury of banana fruit by enhanced antioxidant system and proline content. Sci Horticult. 2015; 183: 144-151.

24. Adamovskaya VG, Molodchenkova OO, Ciselskaya LY, Bezkrovnaya LA, Levitsky YuA. Peculiarities of phenylalanine ammonia-lyase, phenolic compounds and lignin accumulation under the action of Fusarium and salicylic acid in the seedlings of cereal crops. Fiziol Biokhim Kult Rast. 2007; 39(4): 353-361. (In Russian).

25. Li ZG, Xie LR, Li XJ. Hydrogen sulfide acts as a downstream signal molecule in salicylic acidinduced heat tolerance in maize (Zea mays L.) seedlings. J Plant Physiol. 2015; 177: 121-127.

26. Kolupaev YuE, Ryabchun NI, Vayner AA, Yastreb TO, Oboznyi AI. Antioxidant enzyme 
activity and osmolyte content in winter cereal seedlings under hardening and cryostress. Russ J Plant Physiol. 2015; 62(4): 499-506.

27. Zucker M. Induction of phenylalanine ammonialyase in Xanthium leaf disks. Photosynthetic requirement and effect of day length. Plant Physiol. 1969; 44(6): 912-922.

28. Bradford MM. A rapid and sensitive method for the quantitation of microgram quantities of protein utilizing the principle of protein-dye binding. Anal Biochem. 1976; 72(1-2): 248-254.

29. Bulatov AV, Falkova MT, Pushina MO, MoskvinLN,Alekseeva GM.Spectrophotometric determination of flavonoids in plant material. Analitika i Kontrol. 2012; 16(4): 358-362. (In Russian).

30. Harvaux M, Kloppstech K. The protective functions of carotenoid and flavonoid pigments against excess visible radiation at chilling temperature investigated in Arabidopsis npq and tt mutants. Planta. 2001; 213(6): 953-966.

31. Kolupaev YuE, Firsova KM, Shvidenko MV, Yastreb TO. Hydrogen sulfide donor influence on state of antioxidant system of wheat seedlings under osmotic stress. Fiziol Rast Genetika. 2018; 50(1): 29-38. (In Ukrainian).
32. Li Q, Wang Z, Zhao Y, Zhang X, Zhang S, Bo L, Wang Y, Ding Y, An L. Putrescine protects hulless barley from damage due to UV-B stress via $\mathrm{H}_{2} \mathrm{~S}$ - and $\mathrm{H}_{2} \mathrm{O}_{2}$-mediated signaling pathways. Plant Cell Rep. 2016; 35(5): 1155-1168.

33. Aghdama MS, Mahmoudi R, Razavi F, Rabiei V, Soleimani A. Hydrogen sulfide treatment confers chilling tolerance in hawthorn fruit during cold storage by triggering endogenous $\mathrm{H}_{2} \mathrm{~S}$ accumulation, enhancing antioxidant enzymes activity and promoting phenols accumulation. Sci Horticult. 2018; 238: 264-271.

34. Sun Y, Zhang W, Zeng T, Nie Q, Zhang F, Zhu L. Hydrogen sulfide inhibits enzymatic browning of fresh-cut lotus root slices by regulating phenolic metabolism. Food Chem. 2015; 177: 376-381.

35. Liang X, Zhang L, Natarajan SK, Becker DF. Proline mechanisms of stress survival. Antioxid Redox Signal. 2013; 19(9): 998-1011.

36. Hancock JT, Whiteman M. Hydrogen sulfide and cell signaling: team player or referee? Plant Physiol Biochem. 2014; 78: 37-42.

Received 20.08.2018 